\title{
Facultative symbionts associated with aphid populations in citrus orchards in northern Tunisia
}

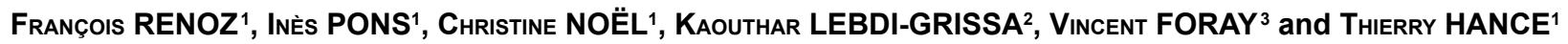 \\ ${ }^{1}$ Earth and Life Institute, Biodiversity Research Centre, UC Louvain, ELIB - Croix du sud 4-5 bte L7.07.04, \\ 1348 Louvain-la-Neuve, Belgium; e-mails: francois.renoz@uclouvain.be, ines.pons@uclouvain.be, \\ christine.noel56@hotmail.com, Thierry.hance@uclouvain.be \\ ${ }^{2}$ Laboratory of Entomology and Acarology, National Agronomic Institute of Tunisia (INAT) - University of Carthage, 43 Avenue \\ Charles Nicolle, Cité Mahrajène, 1082 Tunis, Tunisia, e-mail: grissak@yahoo.fr \\ ${ }^{3}$ Institut de Recherche sur la Biologie de l'Insecte (IRBI), UMR CNRS 7261, 37200 Tours, France; \\ e-mail: vincent.foray@univ-tours.fr
}

Key words. Hemiptera, Aphididae, Aphis gossypii, Aphis spiraecola, Arsenophonus, Serratia symbiotica, co-infection, 16S rRNA, Citrus, Tunisia

\begin{abstract}
Like many insects, aphids (Hemiptera: Aphididae) can host a wide diversity of symbiotic bacteria that can be important drivers of their evolutionary ecology. In addition to the nutritional obligate symbiont Buchnera aphidicola, these phloem-sap feeding insects can host various facultative symbionts whose functional diversity depends on complex interactions with the host genotype and environmental factors. During sampling in citrus orchards in northern Tunisia, we collected aphids on citrus plants. The specimens belonged either to the cotton-melon aphid Aphis gossypii or the green citrus aphid Aphis spiraecola. We analysed the prevalence of Arsenophonus, Serratia symbiotica, Hamiltonella defensa and Regiella insecticola, four facultative symbionts frequently found in the genus Aphis and potentially associated with phenotypic effects related to nutrition, protection against parasites and tolerance of high temperatures. We found that the diversity and prevalence of facultative symbionts differed between these two aphid species that exploit similar ecological niches. In particular, we found a high prevalence of Arsenophonus in $A$. gossypii populations and that the defensive symbiont $H$. defensa was only present in $A$. spiraecola populations. These results are discussed in light of the ecology and life cycles of each of the species of aphid studied.
\end{abstract}

\section{INTRODUCTION}

Like most insects that feed on plant-phloem, aphids (Hemiptera: Aphididae) host symbiotic bacteria in their tissues that can have significant consequences on their evolutionary ecology (Oliver et al., 2010; Ferrari \& Vavre, 2011). The unbalanced diet of these sap-feeding insects renders them dependent on an obligate symbiont, B. aphidicola, which provides them with essential amino acids and vitamins (Douglas, 1998; Russell et al., 2017). Aphids can also carry an array of heritable facultative symbionts (e.g. $H$. defensa, S. symbiotica, R. insecticola, etc.) that occur more sporadically in host insect populations and are maintained in these by vertical transmission and intra- and interspecific horizontal transfers (Sandström et al., 2001; Caspi-Fluger et al., 2011; Gehrer \& Vorburger, 2012). These facultative bacterial partners can impart dramatic phenotypic effects to their host, sometimes beneficial and sometimes harmful depending on specific environmental conditions (Oliver et al., 2006, 2010). The beneficial phenotypic effects include protection against parasitoid wasps and other parasites
(Oliver et al., 2003; Scarborough et al., 2005), tolerance of high temperatures (Montllor et al., 2002; Burke et al., 2010), body colour modification (Tsuchida et al., 2010), host plant use (Tsuchida et al., 2004; Wagner et al., 2015) and reproductive manipulation (Simon et al., 2011).

Since facultative symbionts may have beneficial effects (e.g. defence against parasites, improvement of nutrition, etc.) or detrimental effects on their host (e.g. fitness cost), there is an interest in determining the bacterial partners present in these insects, in particular in species that are crop pests. The presence of these bacteria in aphid populations may interfere with control programs, whether biological (e.g. influence on host resistance to parasitoid wasps) or chemicals (e.g. influence on host susceptibility to insecticides) (Skaljac et al., 2018; Vorburger, 2018). In this study, we examined the prevalence and co-occurrence of Arsenophonus, H. defensa, S. symbiotica and R. insecticola in A. gossypii and A. spiraecola populations infesting citrus plants in northern Tunisia. These two species of aphid are among the most destructive pests of citrus crops 
in the Mediterranean basin (Halima-Kamel \& Hamouda, 2004; Jacas et al., 2010). The four targeted symbionts are frequently found in aphids of the genus Aphis (NajarRodríguez et al., 2009; Brady \& White 2013; Brady et al., 2014; Wulff \& White, 2015) and are known to be involved in a variety of effects including resistance to parasitoids, tolerance of high temperatures and host nutrition (Oliver et al., 2003, 2006; Tsuchida et al., 2004; Burke et al., 2010; Duron, 2014; Wulff \& White, 2015). It is hypothesized that aphids exploiting similar ecological niches, although belonging to different species or to geographically distant populations, tend to exhibit similar combinations of symbionts (McLean et al., 2011; Henry et al., 2013, 2015; Brady et al., 2014). In citrus orchards where the sampling was carried out, A. gossypii and A. spiraecola populations exploit similar niches (e.g. they feed on the same host-plant species, are attacked by the same natural enemies and are subject to similar climactic conditions) (Boukhris-Bouhachem, 2011; Limem Sellami et al., 2013; Elhaddad et al., 2016; Boukhris-Bouhachem et al., 2017). Thus, determining the presence of these facultative symbionts in $A$. gossypii and A. spiraecola also offer the possibility of testing the hypothesis that populations of these two aphid species are likely to host similar combinations of symbionts.

\section{MATERIALS AND METHODS}

\section{Aphid collection}

During sampling in the North of Tunisia [on the Cap Bon peninsula and around the capital Tunis where citrus crops are concentrated (Metoui et al., 2014)], we collected specimens of $A$. gossypii and A. spiraecola (Table S1). The samples consisted of three wingless parthenogenetic adult females from the same colony (i.e. from the same leaf). A total of 68 colonies at 9 locations were sampled. Samples collected at the same location were at least $500 \mathrm{~m}$ apart and came from different orchards. Aphids were stored in $95 \%$ ethanol at $4{ }^{\circ} \mathrm{C}$ until used and then identified based on morphological criteria (Blackman \& Eastop, 2000).

\section{Species-specific screening for facultative symbionts}

DNA of the collected aphids was extracted using the DNeasy Blood \& Tissue Kit (QIAGEN) following the instructions of the manufacturer. Each DNA extraction was performed on a pool of three individuals from the same colony to reduce the risk of missing infection when facultative symbionts are present. We screened each specimen for the facultative symbiont species Arsenophonus, S. symbiotica, $R$. insecticola and H. defensa. We amplified a partial region of the $16 \mathrm{~S}$ rRNA gene using specific primers (Table 1). The PCR assays were performed in a final volume of $15 \mu \mathrm{l}$ containing $1 \mu \mathrm{l}$ of the template DNA lysate, 0.5 $\mu \mathrm{M}$ of each primer, $200 \mu \mathrm{M}$ dNTP's, $1 \times$ buffer and 0.625 unit of Taq DNA polymerase (Roche). The PCR reaction conditions consisted of 40 cycles of $95^{\circ} \mathrm{C}$ for $1 \mathrm{~min}, 55^{\circ} \mathrm{C}$ for $1 \mathrm{~min} 30 \mathrm{~s}$ and $72^{\circ} \mathrm{C}$ for $1 \mathrm{~min} 30 \mathrm{~s}$. DNA samples found positive for the different symbiont species in the context of a previous deep 16S rRNA sequencing analysis were used as positive controls (Fakhour et al., 2018). Negative controls consisted of sterilized water instead of genomic DNA. The PCR products were stained with ethidium bromide and visualized on a $1 \%$ agarose gel. Half of the amplified samples were sequenced and the resulting sequences were validated using BLAST on GenBank.

\section{Statistical analyses}

To evaluate potential factors contributing to the facultative symbiont infections, generalized linear models (GLMs) were examined on the basis of the presence/absence of the respective facultative symbionts in the two species of aphid (binomial error structure, logit-link functions). For each facultative symbiont, the model considered the species of aphid and site sampled as fixed factors. We also carried out Fisher's exact tests to compare the global distribution of facultative symbionts between aphid species. To test the levels of co-occurrence of facultative symbionts, we performed a multiple regression analysis of the presence/absence of each symbiont against that of the other symbionts using generalized linear mixed models (binomial-error and logit-link functions). Finally, the graphical representation of facultative symbiont communities was done using the Mondrian function implemented in R (Gueguen et al., 2010). All statistical analyses were performed using the software $\mathrm{R}$ version 3.6.1 (R Development Core team, 2014).

\section{RESULTS}

Of the 68 citrus aphid colonies sampled at 9 locations in northern Tunisia, we identified 19 colonies of the cotton-melon aphid, $A$. gossypii, and 49 colonies of the green citrus aphid, A. spiraecola. For A. gossypii, 89\% (17/19) of the colonies were infected, whereas only $45 \%(22 / 49)$ of the A. spiraecola colonies were positive for facultative symbionts (Fig. 1). In general, these two aphids differed in terms of the species composition of their symbionts (Fisher's exact test, $\mathrm{p}<0.0001$ ). More precisely, for $\mathrm{Ar}$ senophonus, its prevalence was significantly higher in $A$. gossypii than in A. spiraecola $\left(\chi^{2}=18.38, \mathrm{df}=1, \mathrm{p}<0.001\right.$, Fig. 2A). Arsenophonus was clearly the facultative symbiont that was most frequently recorded in the citrus aphids studied with a prevalence reaching $73 \%(14 / 19)$ in $A$. gossypii, either as a single infection (47\%) or in combination with other symbionts (26\%) (Fig. 1). In A. spiraecola colonies, the prevalence of this symbiont was $18 \%(9 / 49)$. In terms of infection with the symbionts S. symbiotica and

Table 1. Primers used in this study.

\begin{tabular}{|c|c|c|c|c|c|c|}
\hline Gene & Product & Primers $\left(5^{\prime}-3^{\prime}\right)$ & & $\mathrm{Tm}$ & $\begin{array}{l}\text { Fragment } \\
\text { size }(b p)\end{array}$ & References \\
\hline $\begin{array}{l}\text { Arsenophonus sp. } \\
\text { 16S rRNA }\end{array}$ & Ribosomal RNA & $\begin{array}{l}\text { 16SA1F } \\
\text { Ars16SR }\end{array}$ & $\begin{array}{l}\text { AGAGTTTGATCMTGGCTCAG } \\
\text { GCAATGTCTTATTAACACAT }\end{array}$ & $55^{\circ} \mathrm{C}$ & 960 & $\begin{array}{l}\text { Fukatsu \& Nikoh, } 1998 \\
\text { Tsuchida et al., } 2002\end{array}$ \\
\hline $\begin{array}{l}\text { Serratia symbiotica } \\
16 \text { S rRNA }\end{array}$ & Ribosomal RNA & $\begin{array}{c}\text { 16SA1F } \\
\text { PASScmpR }\end{array}$ & $\begin{array}{l}\text { AGAGTTTGATCMTGGCTCAG } \\
\text { GCAATGTCTTATTAACACAT }\end{array}$ & $55^{\circ} \mathrm{C}$ & 480 & $\begin{array}{l}\text { Fukatsu \& Nikoh, } 1998 \\
\text { Fukatsu et al., } 2000\end{array}$ \\
\hline $\begin{array}{l}\text { Regiella insecticola } \\
16 \mathrm{~S} \text { rRNA }\end{array}$ & Ribosomal RNA & $\begin{array}{l}\text { U99F } \\
\text { 16SB4 }\end{array}$ & $\begin{array}{l}\text { ATCGGGGAGTAGCTTGCTAC } \\
\text { CTAGAGATCGTCGCCTAGGTA }\end{array}$ & $55^{\circ} \mathrm{C}$ & 200 & $\begin{array}{l}\text { Sandström et al., } 2001 \\
\text { Tsuchida et al., } 2002\end{array}$ \\
\hline $\begin{array}{l}\text { Hamiltonella defensa } \\
16 \mathrm{~S} \text { rRNA }\end{array}$ & Ribosomal RNA & $\begin{array}{l}\text { PABSF } \\
16 S B 1\end{array}$ & $\begin{array}{l}\text { AGCACAGTTTACTGAGTTCA } \\
\text { TACGGYTACCTTGTTACGACTT }\end{array}$ & $55^{\circ} \mathrm{C}$ & 1660 & $\begin{array}{l}\text { Darby et al., } 2002 \\
\text { Fukatsu \& Nikoh, } 1998\end{array}$ \\
\hline
\end{tabular}


A

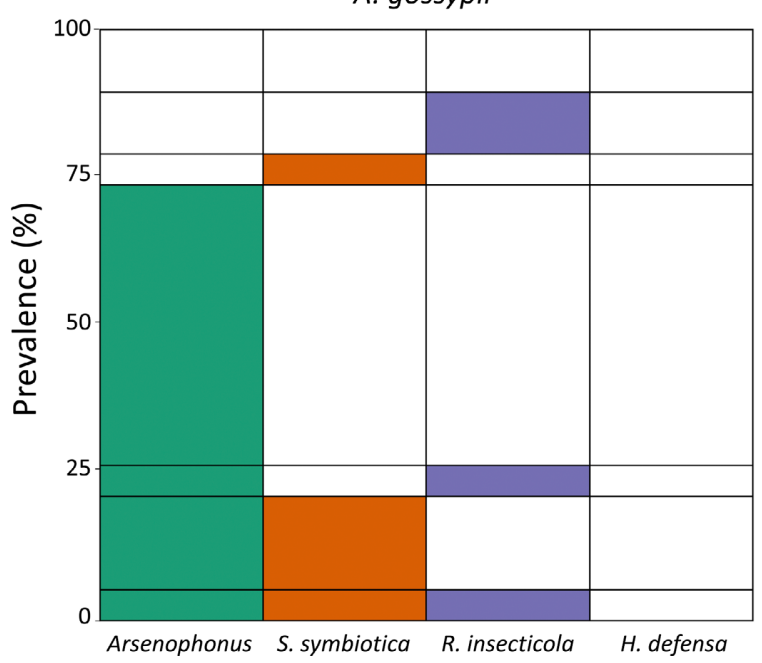

B

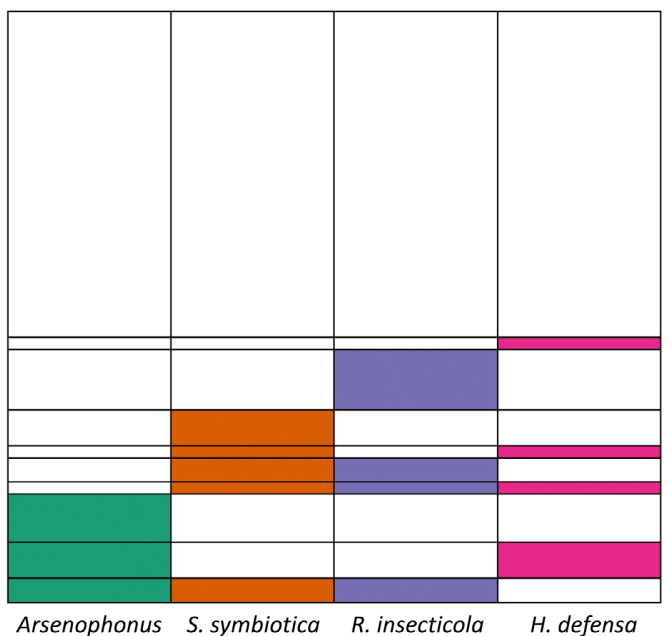

Fig. 1. Structure of facultative bacterial symbiont communities recorded in (A) $A$. gossypii $(\mathrm{N}=19)$ and $(\mathrm{B}) A$. spiraecola $(\mathrm{N}=49)$. Uninfected individuals are depicted in white. For each column, the coloured area corresponds to the total prevalence of this symbiont in a particular species of aphid (corresponding to different sampled populations). Rows consisting of several coloured areas indicate multiple infections of the same sample, but do not necessarily reflect co-infection of the same aphid, because each sample consisted of three aphids from the same colony.

$R$. insecticola there was no significant difference between the two species of aphid (S. symbiotica: $\chi^{2}=0.51, \mathrm{df}=1$, $\mathrm{p}=0.47 ;$ R. insecticola: $\chi^{2}=0.0035, \mathrm{df}=1, \mathrm{p}=0.95$, Fig. 2B, C). S. symbiotica occurred either as a single infection or in combination with other facultative symbionts in both species with a prevalence of $26 \%(5 / 19)$ in $A$. gossypii and $16 \%(8 / 49)$ in $A$. spiraecola. The prevalence of $R$. insecticola was about $20 \%$ in both aphids. Finally, for $H$. defensa the prevalence of infection was significantly higher

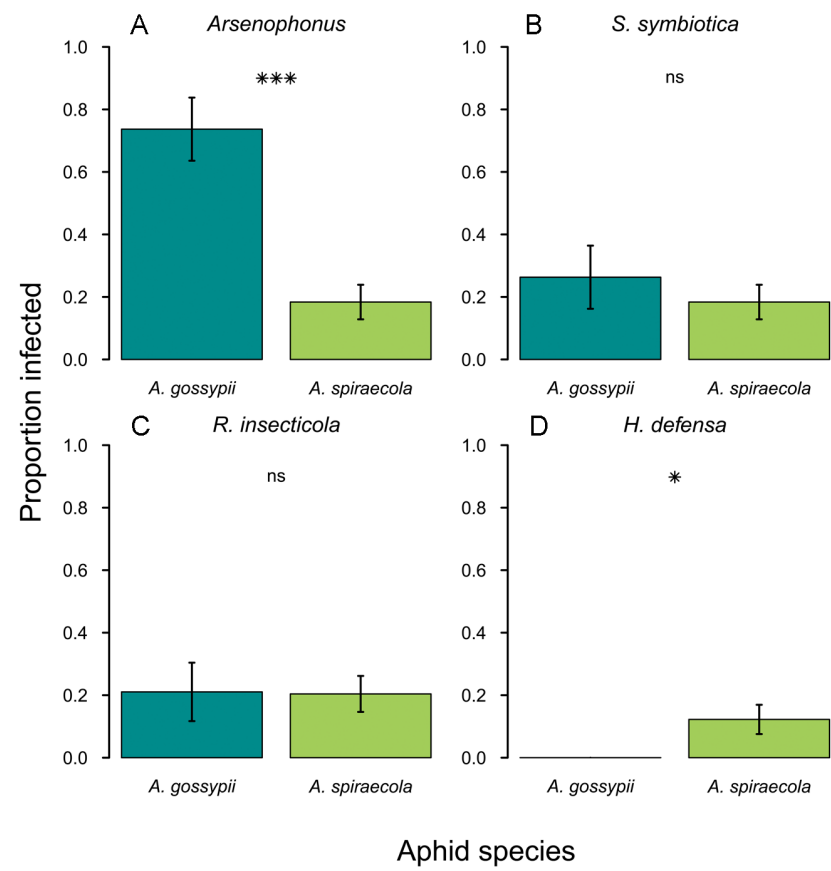

Fig. 2. Proportion of aphids infected with facultative symbionts targeted in natural populations of $A$. gossypii $(\mathrm{N}=19)$ and $A$. spiraecola $(\mathrm{N}=49)$. A - Arsenophonus, B $-S$. symbiotica, $\mathrm{C}-R$. insecticola, D - H. defensa. Error bars depict the standard error. Significant differences are shown (ns - not significant; ${ }^{*}-p<0.05$ $* * *-p<0.001)$ in $A$. spiraecola than in $A$. gossypii $\left(\chi^{2}=4.15, \mathrm{df}=1, \mathrm{p}=\right.$ 0.042 , Fig. 2D) as it was not detected in $A$. gossypii but the prevalence of infection of $A$. spiraecola colonies was $12 \%(6 / 49)$. In terms of the sites sampled, there was no significant difference between sites for Arsenophonus ( $\chi^{2}$ $=11.62, \mathrm{df}=8, \mathrm{p}=0.17)$ and $R$. insecticola symbionts $\left(\chi^{2}=12.29, \mathrm{df}=8, \mathrm{p}=0.14\right)$, but for S. symbiotica and $H$. defensa, the prevalence of infection was significantly dependent on the site sampled (S. symbiotica: $\chi^{2}=21.48, \mathrm{df}$ $=8, \mathrm{p}=0.006 ; H$. defensa: $\left.\chi^{2}=22.61, \mathrm{df}=8, \mathrm{p}=0.0039\right)$.

We also determined the prevalence of multiple infections, that is, the presence of more than one facultative symbiont species in the same sample. Twenty-one percent $(14 / 68)$ of the samples were infected by at least two facultative symbionts. For $A$. gossypii, all possible combinations of Arsenophonus, S. symbiotica and R. insecticola were recorded other than a dual infection with $S$. symbiotica and $R$. insecticola (Fig. 1A). For A. spiraecola, we recorded single infections with each symbiont, but samples with two or three symbionts were uncommon and followed no discernible pattern (Fig. 1B). If we only consider those samples infected with at least one facultative symbiont, the prevalence of multiple infections is $29 \%(5 / 17)$ in $A$. gossypii and 41\% (9/22) in A. spiraecola with no significant difference between the two aphids (Fisher's exact test, $p$ $=0.52$ ). However, none of the combinations were recorded significantly more or less frequently than expected by chance. Even the combination Arsenophonus-S. symbiotica of $16 \%$ (3/19) for the A. gossypii samples did not deviate significantly from a random association $\left(\chi^{2}=0.14512\right.$, $\mathrm{df}=1, \mathrm{p}=0.70)$.

\section{DISCUSSION}

In this study, we collected citrus aphids from orchards in northern Tunisia. We identified the individuals collected and found that they all belonged to either the species $A$. 
gossypii or A. spiraecola. We determined whether these two species were infected with facultative symbionts. Four symbionts, namely Arsenophonus, S. symbiotica, $R$. insecticola and $H$. defensa, were recorded either in $A$. gossypii or $A$. spiraecola. These symbionts are widely recorded occurring in the genus Aphis (Carletto et al., 2008; Jones et al., 2011; Brady \& White, 2013; Jousselin et al., 2013; Arneodo \& Ortego, 2014; Brady et al., 2014; Wulff \& White, 2015; Zhao et al., 2016; Zytynska \& Weisser, 2016; Desneux et al., 2018) and are known to have associated effects that may contribute to the ecological success of their host. The majority of the A. spiraecola samples were not infected with facultative symbionts, although all the targeted symbionts were detected in this species. However, in $A$. gossypii, the presence of at least one facultative symbiont is almost systematic. $H$. defensa was recorded in A. spiraecola but not in $A$. gossypii even though previous studies have reported the presence of $H$. defensa in this aphid (Zhao et al., 2016; Ayoubi et al., 2020). We recorded similar percentage infections of $A$. gossypii and $A$. spiraecola with $S$. symbiotica and $R$. insecticola, but the percentage infection of these aphids with Arsenophonus differed. In A. gossypii populations, the prevalence of Arsenophonus was around $75 \%$, which is similar to that recorded in other studies (Jones et al., 2011; Zhao et al., 2016; Ayoubi et al., 2018; Zhang et al., 2018).

Although the effects associated with the symbionts identified in $A$. gossypii and A. spiraecola are unknown, inferences can be drawn based on their functions in other aphid species. $H$. defensa is well known for protecting the pea aphid A. pisum (Oliver et al., 2003, 2009; Weldon et al., 2013) and black bean aphid Aphis fabae (Schmid et al., 2012; Rouchet \& Vorburger, 2014) against parasitoids. In $A$. pisum, $S$. symbiotica has some ability to protect its host against parasitoids (Oliver et al., 2006; Pons et al., 2019) and high temperatures (Montllor et al., 2002; Burke et al., 2010). $R$. insecticola is reported to affect the performance of $A$. pisum on host plants (Tsuchida et al., 2004) and protect $A$. fabae against parasitoids (Vorburger et al., 2010). The effects associated with Arsenophonus are unclear. Bacteriophages required for protective symbiosis are recorded in various strains of this symbiont (Duron, 2014), but no defensive properties are reported for Aphis glycines infected with Arsenophonus (Wulff et al., 2013). Due to the high prevalence of Arsenophonus in populations of $A$. gossypii it is suggested that this facultative symbiont may be involved in host nutrition by mediating host plant range (Wagner et al., 2015; Zhao et al., 2016; Tian et al., 2019; Ayoubi et al., 2020).

Previous large-scale surveys indicate that aphids exploiting similar ecological niches, although belonging to different species or geographically distant populations, tend to have similar combinations of facultative symbionts (Ferrari et al., 2012; Henry et al., 2013, 2015; Brady et al., 2014; Wagner et al., 2015). In our study, A. gossypii and $A$. spiraecola were collected from similar food resources (i.e. citrus plants) distributed over a small geographical area and therefore subject to similar climatic conditions. In ad- dition, the two species share many natural enemies (Boukhris-Bouhachem, 2011; Limem Sellami et al., 2013), are frequently tended by ants (Kaneko, 2018; Karami-Jamour et al., 2018) and transmit the same viruses, such as citrus tristeza virus (CTV) (Elhaddad et al., 2016; Boukhris-Bouhachem et al., 2017). In our study, the two aphids differ in terms of symbiont composition, while they occupy very similar ecological niches. The factors that may determine the presence of facultative symbionts in aphid populations remain poorly understood. A recent study indicates that the bacterial flora associated with $A$. gossypii is strongly affected by its host plants (Xu et al., 2019). However, other studies indicate that the composition of microbial communities hosted by aphids may largely depend on host genotype (Fakhour et al., 2018; McLean et al., 2019). In addition, it is possible that microclimatic conditions and other local variables (natural enemies, surrounding vegetation, etc.) have a major influence on the structure of symbiotic communities (Zytynska et al., 2019). A. gossypii and A. spiraecola are both highly polyphagous species and can readily switch from one host plant species to another. Therefore, it is also possible that their feeding behaviour and the food environment they encountered previously determines the composition of the symbiont community associated with them.

There was a high incidence of multiple infections, of up to $42 \%$, in the $A$. spiraecola samples, which did not differ from that recorded for $A$. gossypii. Further, there was no evidence for preferential associations or the exclusion of particular symbionts. Multiple infections by facultative symbionts are mostly reported for the pea aphid A. pisum (Leonardo \& Muiru, 2003; Oliver et al., 2006; Nyabuga et al., 2010; Ferrari et al., 2012; Henry et al., 2013; Russell et al., 2013). The reports for the genus Aphis are conflicting as $A$. fabae, A craccivora and $A$. gossypii are rarely reported hosting more than one facultative symbiont (Chandler et al., 2008; Najar-Rodríguez et al., 2009; Brady et al., 2014; Henry et al., 2015; Zhao et al., 2016; Zhang et al., 2018) whereas one individual of the black bean aphid $A$. fabae can harbour up to four different symbionts (Zytynska et al., 2015). Our results are consistent with the latter study and indicate that multiple infections by different symbionts are probably less rare in the genus Aphis than previously thought. However, in the context of this study, artefacts due to the methodology cannot be excluded. Indeed, we assessed the presence of facultative symbionts using three individuals per colony and contamination from other colonies cannot be completely excluded. Host infection by several facultative symbionts is known to affect host fitness in different ways dependent on the symbionts involved (Oliver et al., 2006; Łukasik et al., 2013; Tsuchida et al., 2014; Leclair et al., 2016). Specific multiple infection patterns could either result in an amplification of the beneficial effects associated with each symbiont (Oliver et al., 2006) or in severe costs for host aphids (Oliver et al., 2006). However, apparent preferential associations or exclusion of symbionts might be explained by drift in certain cases (Mathé-Hubert et al., 2019). Patterns of multiple infections 
in species of aphids may also depend on specific features related to their respective lifecycle, such as feeding behaviour (i.e. the degree of polyphagy), alternation between a primary and a secondary host plants (i.e. heteroecious cycle) or a sexual reproductive phase that promotes the exchange of facultative symbionts between males and females (Moran \& Dunbar, 2006).

In conclusion, the prevalence of several facultative symbionts in populations of two species of aphids was quantified. In the citrus orchards in northern Tunisia, A. gossypii and $A$. spiraecola exploit similar niches and are major pests. It is important to keep in mind that, despite the fact that the four targeted symbiont species are frequently found in aphids of the genus Aphis, other facultative symbionts can infect these aphids. For example, several studies report the presence of Wolbachia in A. gossypii (Jones et al., 2011; Zhao et al., 2016). In addition, like other field studies, this study is a snapshot as the prevalence of symbionts in insect populations can change depending on environmental pressures. However, it is relevant to evaluate the presence of facultative bacteria in insect pests, as in addition to being beneficial for their hosts they may make them more vulnerable to certain stresses. Due to their associated effects, bacterial symbionts can interfere with control programs, be it biological control or chemical control.

\section{DECLARATION OF INTEREST. None.}

AUTHOR CONTRIBUTIONS. FR conceived and designed the study; VF and KLG sampled the aphids; FR, IP and CN did the research; FR, VF and IP analysed the data; FR wrote the first draft of the manuscript; IP, VF and TH revised the manuscript. All authors approved the manuscript for publication.

ACKNOWLEDGEMENTS. This work was supported by the Fonds pour la Formation à la Recherche dans l'Industrie et dans l'Agriculture (FRIA grant no. 1.E074.14) and the FRS-FNRS in Belgium (FRFC 6886819) (http://www.fnrs.be). Field sampling was possible due to a grant from Wallonie-Bruxelles-International (WBI) in the context of bilateral cooperation between Tunisia and Belgium (Axe 2 - Lutte biologique contre les ravageurs en cultures d'agrumes 2012-2014). The funding agencies had no role in the design of the study, data collection and analysis, decision to publish or preparation of the manuscript. This paper is publication BRC 342 of the Biodiversity Research centre (UCL/ ELI/BDIV).

\section{REFERENCES}

ARnEOdo J.D. \& ORTEGo J. 2014: Exploring the bacterial microbiota associated with native South American species of Aphis (Hemiptera: Aphididae). — Environ. Entomol. 43: 589-594.

Ayoubi A., Talebi A.A., Fathipour Y. \& Mehrabadi M. 2020: Coinfection of the secondary symbionts, Hamiltonella defensa and Arsenophonus sp. contribute to the performance of the major aphid pest, Aphis gossypii (Hemiptera: Aphididae). Insect Sci. 27: 86-98.

Blackman R.L. \& EAStop V.F. 2000: Aphids on the World's Crops: An Identification and Information Guide. Wiley-Blackwell, New York, 476 pp.

Boukhris-BouHachem S. 2011: Aphid enemies reported from Tunisian Citrus orchards. - Tunis. J. Plant Prot. 6: 21-28.
Boukhris-Bouhachem S., Ben Fekih I., Nahdi S. \& Souissi R. 2017: Capacity assessment of Myzus persicae, Aphis gossypii and Aphis spiraecola (Hemiptera: Aphididae) to acquire and retain PVYNTN in Tunisia. - Arthr.-Plant Interact. 11: 669674.

Brady C.M. \& White J.A. 2013: Cowpea aphid (Aphis craccivo$r a$ ) associated with different host plants has different facultative endosymbionts. - Ecol. Entomol. 38: 433-437.

Brady C.M., Asplen M.K., Desneux N., Heimpel G.E., Hopper K.R., Linnen C.R., Oliver K.M., WulfF J.A. \& White J.A. 2014: Worldwide populations of the aphid Aphis craccivora are infected with diverse facultative bacterial symbionts. Microb. Ecol. 67: 195-204.

Burke G., Fiehn O. \& Moran N. 2010: Effects of facultative symbionts and heat stress on the metabolome of pea aphids. ISME J. 4: 242-252.

Carletto J., Gueguen G., Fleury F. \& Vanlerberghe-Masutti F. 2008: Screening the bacterial endosymbiotic community of sap-feeding insects by terminal-restriction fragment length polymorphism analysis. — Entomol. Exp. Appl. 129: 228-234.

Caspi-Fluger A., Inbar M., Mozes-Daube N., Katzir N., Portnoy V., Belausov E., Hunter M.S. \& Zchori-Fein E. 2011: Horizontal transmission of the insect symbiont Rickettsia is plant-mediated. - Proc. R. Soc. Lond. (B) 279: 1791-1796.

Chandler S.M., Wilkinson T.L. \& Douglas A.E. 2008: Impact of plant nutrients on the relationship between a herbivorous insect and its symbiotic bacteria. - Proc. R. Soc. Lond. (B) 275: $565-570$.

Desneux N., Asplen M.K., Brady C.M., Heimpel G.E., Hopper K.R., Luo C., Monticelli L., Oliver K.M. \& White J.A. 2018: Intraspecific variation in facultative symbiont infection among native and exotic pest populations: Potential implications for biological control. - Biol. Contr. 116: 27-35.

Douglas A.E. 1998: Nutritional interactions in insect-microbial symbioses: Aphids and their symbiotic bacteria Buchnera. Annu. Rev. Entomol. 43: 17-37.

Duron O. 2014: Arsenophonus insect symbionts are commonly infected with APSE, a bacteriophage involved in protective symbiosis. - FEMS Microbiol. Ecol. 90: 184-194.

Elhaddad A., ElAmrani A., Fereres A. \& Moreno A. 2016: Spatial and temporal spread of Citrus tristeza virus and its aphid vectors in the North western area of Morocco. - Insect Sci. 23: 903-912.

Fakhour S., Ambroise J., Renoz F., Foray V., Gala J.-L. \& Hance T. 2018: A large-scale field study of bacterial communities in cereal aphid populations across Morocco. - FEMS Microbiol. Ecol. 94(3): 11 pp.

Ferrari J. \& VAVRe F. 2011: Bacterial symbionts in insects or the story of communities affecting communities. - Philos. Trans. R. Soc. (B) 366: 1389-1400.

Ferrari J., West J.A., Via S. \& Godfray H.C.J. 2012: Population genetic structure and secondary symbionts in host-associated populations of the pea aphid complex. - Evolution 66: 375390.

Gehrer L. \& Vorburger C. 2012: Parasitoids as vectors of facultative bacterial endosymbionts in aphids. - Biol. Lett. 8: 613-615.

Gueguen G., Vavre F., Gnankine O., Peterschmitt M., Charif D., Chiel E., Gottlieb Y., Ghanim M., Zchori-Fein E. \& Fleury F. 2010: Endosymbiont metacommunities, mtDNA diversity and the evolution of the Bemisia tabaci (Hemiptera: Aleyrodidae) species complex. - Mol. Ecol. 19: 4365-4376.

Halima-Kamel M.B. \& Hamouda M.H.B. 2004: Aphids of fruit trees in Tunisia. In Simon J.C., Dedryver C.A., Rispe C. \& 
Hulle M. (eds): Aphids in a New Millennium. INRA, Paris, pp. $119-124$.

Henry L.M., Peccoud J., Simon J.-C., Hadfield J.D., Maiden M.J.C, FerRari J. \& Godfray H.C.J. 2013: Horizontally transmitted symbionts and host colonization of ecological niches. - Curr. Biol. 23: 1713-1717.

Henry L.M., Maiden M.C.J., Ferrari J. \& Godfray H.C.J. 2015: Insect life history and the evolution of bacterial mutualism. Ecol. Lett. 18: 516-525.

Jacas J.A., Karamaouna F., Vercher R. \& Zappalà L. 2010: Citrus Pest Management in the Northern Mediterranean Basin (Spain, Italy and Greece). In Ciancio A. \& Mukerji K.G. (eds): Integrated Management of Arthropod Pests and Insect Borne Diseases, Integrated Management of Plant Pests and Diseases. Springer, Dordrecht, pp. 3-27.

Jones R.T., Bressan A., Greenwell A.M. \& Fierer N. 2011: Bacterial communities of two parthenogenetic aphid species cocolonizing two host plants across the Hawaiian Islands. - Appl. Environ. Microbiol. 77: 8345-8349.

Jousselin E., D’Acier A.C., Vanlerberghe-Masutti F. \& Duron O. 2013: Evolution and diversity of Arsenophonus endosymbionts in aphids. - Mol. Ecol. 22: 260-270.

KANEKO S. 2018: Seasonal differences in the abundance of an ant-adapted parasitoid, Lysiphlebus japonicus (Hymenoptera: Aphidiidae), in ant-attended colonies of the spirea aphid Aphis spiraecola (Hemiptera: Aphididae) on citrus: comparison for two ant species, Lasius japonicus and Pristomyrmex punctatus (Hymenoptera: Formicidae). - Appl. Entomol. Zool. 53: 315-321.

Karami-Jamour T., Mirmoayedi A., Zamani A. \& Khajehzadeh Y. 2018: The impact of ant attendance on protecting Aphis gossypii against two aphidophagous predators and it's role on the intraguild predation between them. - J. Insect Behav. 31: 222-239.

Leclair M., Polin S., Jousseaume T., Simon J.-C., Sugio A., Morlière S., Fukatsu T., Tsuchida T. \& Outreman Y. 2016: Consequences of co-infection with protective symbionts on the host phenotype and symbiont titres in the pea aphid system. - Insect Sci. 24: 798-808.

Leonardo T.E. \& Muiru G.T. 2003: Facultative symbionts are associated with host plant specialization in pea aphid populations. - Proc. R. Soc. Lond. (B) 270: S209-S212.

Limem Sellami E., Delvare G. \& Chermiti B. 2013: Parasitoids and hyperparasites of citrus aphids in northern east of Tunisia (Cap Bon). - IOBC/WPRS Bull. 95: 131-139.

Łukasik P., Guo H., van Asch M., Ferrari J. \& Godfray H.C.J. 2013: Protection against a fungal pathogen conferred by the aphid facultative endosymbionts Rickettsia and Spiroplasma is expressed in multiple host genotypes and species and is not influenced by co-infection with another symbiont. - J. Evol. Biol. 26: 2654-2661.

Mathé-Hubert H., Kaech H., Hertaeg C., Jaenike J. \& VorburgER C. 2019: Nonrandom associations of maternally transmitted symbionts in insects: The roles of drift versus biased cotransmission and selection. - Mol. Ecol. 28: 5330-5346.

McLean A.H.C, Asch M., Ferrari J. \& Godfray H.C.J. 2011: Effects of bacterial secondary symbionts on host plant use in pea aphids. - Proc. R. Soc. Lond. (B) 278: 760-766.

McLean A.H.C, Godfray H.C.J, Ellers J. \& Henry L.M. 2019 Host relatedness influences the composition of aphid microbiomes. - Environ. Microbiol. Rep. 11: 808-816.

Metoui N., Hamrouni L., Dhaoudi F. \& Bettaieb T. 2014: Notes ethnobotanique et phytopharmacologique sur la Maltaise de Tunisie. - Phytothérapie 12: 105-108.
Montllor C.B., Maxmen A. \& Purcell A.H. 2002: Facultative bacterial endosymbionts benefit pea aphids Acyrthosiphon pisum under heat stress. - Ecol. Entomol. 27: 189-195.

Moran N.A. \& Dunbar H.E. 2006: Sexual acquisition of beneficial symbionts in aphids. - Proc. Natl. Acad. Sci. 103: 12803-12806.

Najar-Rodríguez A.J., McGraw E.A., Mensah R.K., Pittman G.W. \& Walter G.H. 2009: The microbial flora of Aphis gossypii: Patterns across host plants and geographical space. $-J$. Invertebr. Pathol. 100: 123-126.

Nyabuga F.N., Outreman Y., Simon J.-C., Heckel D.G. \& WeisSER W.W. 2010: Effects of pea aphid secondary endosymbionts on aphid resistance and development of the aphid parasitoid Aphidius ervi: a correlative study. — Entomol. Exp. Appl. 136: 243-253.

Oliver K.M., Russell J.A., Moran N.A. \& Hunter M.S. 2003: Facultative bacterial symbionts in aphids confer resistance to parasitic wasps. - Proc. Natl. Acad. Sci. 100: 1803-1807.

Oliver K.M., Moran N.A. \& Hunter M.S. 2006: Costs and benefits of a superinfection of facultative symbionts in aphids. Proc. R. Soc. Lond. (B) 273: 1273-1280.

Oliver K.M., Degnan P.H., Hunter M.S. \& Moran N.A. 2009: Bacteriophages encode factors required for protection in a symbiotic mutualism. - Science 325: 992-994.

Oliver K.M., Degnan P.H., Burke G.R. \& Moran N.A. 2010: Facultative symbionts in aphids and the horizontal transfer of ecologically important traits. - Annu. Rev. Entomol. 55: 247-266.

Pons I., Renoz F., NoËl C. \& Hance T. 2019: New insights into the nature of symbiotic associations in aphids: Infection process, biological effects and transmission mode of cultivable Serratia symbiotica bacteria. - Appl. Environ. Microbiol. 85(10): e02445-18, 15 pp.

ROUCHET R. \& VORBURGER C. 2014: Experimental evolution of parasitoid infectivity on symbiont-protected hosts leads to the emergence of genotype specificity. — Evolution 68: 16071616.

Russell J.A., Weldon S., Smith A.H., Kim K.L., Hu Y., ŁuKasiK P., Doll S., Anastopoulos I., Novin M. \& Oliver K.M. 2013: Uncovering symbiont-driven genetic diversity across North American pea aphids. - Mol. Ecol. 22: 2045-2059.

Russell J.A., Oliver K.M. \& Hansen A.K. 2017: Band-aids for Buchnera and B vitamins for all. — Mol. Ecol. 26: 2199-2203.

Sandström J.P., Russell J.A., White J.P. \& Moran N.A. 2001: Independent origins and horizontal transfer of bacterial symbionts of aphids. - Mol. Ecol. 10: 217-228.

Scarborough C.L., Ferrari J. \& Godfray H.C.J. 2005. Aphid protected from pathogen by endosymbiont. - Science 310: 1781-1781.

Schmid M., Sieber R., Zimmermann Y.-S. \& Vorburger C. 2012: Development, specificity and sublethal effects of symbiontconferred resistance to parasitoids in aphids. - Funct. Ecol. 26: 207-215.

Simon J.-C., Boutin S., Tsuchida T., Koga R., Le Gallic J.-F., Frantz A., Outreman Y. \& Fukatsu T. 2011: Facultative Symbiont infections affect aphid reproduction. - PLOS ONE 6(7): e21831, 10 pp.

Skaljac M., Kirfel P., Grotmann J. \& Vilcinskas A. 2018: Fitness costs of infection with Serratia symbiotica are associated with greater susceptibility to insecticides in the pea aphid Acyrthosiphon pisum. — Pest Manag. Sci. 74: 1829-1836.

Tian P.-P., Chang C.-Y., Miao N.-H., Li M.-Y. \& Liu X.-D. 2019: The facultative endosymbiont Arsenophonus infections alter aphid (Aphis gossypii) performance on the amino acid-deficient diet. - Appl. Environ. Microbiol. 85(23): e01407-19, 11 pp. 
Tsuchida T., Koga R. \& Fukatsu T. 2004: Host plant specialization governed by facultative symbiont. - Science 303: 1989.

Tsuchida T., Koga R., Horikawa M., Tsunoda T., Maoka T., Matsumoto S., Simon J.-C. \& FuKatsu T. 2010: Symbiotic bacterium modifies aphid body color. - Science 330: 1102-1104.

Tsuchida T., Koga R., Funiwara A. \& Fukatsu T. 2014: Phenotypic effect of "Candidatus Rickettsiella viridis," a facultative symbiont of the pea aphid (Acyrthosiphon pisum), and its interaction with a coexisting symbiont. - Appl. Environ. Microbiol. 80: 525-533.

Vorburger C. 2018: Symbiont-conferred resistance to parasitoids in aphids - Challenges for biological control. - Biol. Contr. 116: 17-26.

Vorburger C., Gehrer L. \& Rodriguez P. 2010: A strain of the bacterial symbiont Regiella insecticola protects aphids against parasitoids. - Biol. Lett. 6: 109-111.

Wagner S.M., Martinez A.J., Ruan Y.-M., Kim K.L., Lenhart P.A., Dehnel A.C., Oliver K.M. \& White J.A. 2015: Facultative endosymbionts mediate dietary breadth in a polyphagous herbivore. - Funct. Ecol. 29: 1402-1410.

Weldon S.R., Strand M.R. \& Oliver K.M. 2013: Phage loss and the breakdown of a defensive symbiosis in aphids. - Proc. $R$. Soc. (B) 280: 20122103, 7 pp.

WulfF J.A. \& White J.A. 2015: The endosymbiont Arsenophonus provides a general benefit to soybean aphid (Hemiptera: Aphididae) regardless of host plant resistance (Rag). - Environ. Entomol. 44: 574-581.

WulfF J.A., Buckman K.A., Wu K., Heimpel G.E. \& White J.A. 2013: The endosymbiont Arsenophonus is widespread in soy- bean aphid, Aphis glycines, but does not provide protection from parasitoids or a fungal pathogen. - PLOS ONE 8(4): e62145, 7 pp.

Xu S., Jiang L., Qiao G. \& Chen J. 2019: The bacterial flora associated with the polyphagous aphid Aphis gossypii Glover (Hemiptera: Aphididae) is strongly affected by host plants. Microb. Ecol. [in press] doi: 10.1007/s00248-019-01435-2.

Zhang S., Luo J., Wang L., Zhang L., Zhu X., Jiang W. \& Cui J. 2018: Bacterial communities in natural versus pesticide-treated Aphis gossypii populations in North China. - Microbiol. Open 8: e652, $10 \mathrm{pp}$.

Zhao Y., Zhang S., Luo J.-Y., Wang C.-Y., Lv L.-M. \& CuI J.-J. 2016: Bacterial communities of the cotton aphid Aphis gossypii associated with Bt cotton in northern China. - Sci. Rep. 6: 22958, 8 pp.

Zytynska S.E. \& Weisser W.W. 2016: The natural occurrence of secondary bacterial symbionts in aphids. - Ecol. Entomol. 41: 13-26.

Zytynska S.E., Meyer S.T., Sturm S., Ullmann W., Mehrparvar M. \& WEISSER W.W. 2015: Secondary bacterial symbiont community in aphids responds to plant diversity. — Oecologia 180: 735-747.

Zytynska S.E., Thighiouart K. \& Frago E. 2019: A meta-analysis on the benefits and costs of hosting secondary endosymbionts in sap-sucking insects. - bioRxiv URL: https://doi. org/10.1101/563031, 19 pp.

Received November 22, 2019; revised and accepted March 19, 2020 Published online April 9, 2020

Table S1. Detection of the targeted facultative symbionts in the different colonies of $A$. spiraecola and $A$. gossypii in different regions of the North of Tunisia.

\begin{tabular}{|c|c|c|c|c|c|c|c|c|}
\hline Colony ID & $\begin{array}{l}\text { Sampling } \\
\text { date }\end{array}$ & Collection site & Aphid species & Host plant species & Arsenophonus & $\begin{array}{c}\text { S. } \\
\text { symbiotica }\end{array}$ & $\begin{array}{c}R . \\
\text { insecticola }\end{array}$ & $\begin{array}{c}H . \\
\text { defensa }\end{array}$ \\
\hline 1 & $31 / 04 / 2013$ & Béni Khalled & A. gossypii & Citrus sinensis & + & + & & \\
\hline 2 & $31 / 04 / 2013$ & Béni Khalled & A. gossypii & Citrus sinensis & + & + & & \\
\hline 3 & $31 / 04 / 2013$ & Menzel Bouzelfa & A. gossypii & $\begin{array}{l}\text { Citrus sinensis } \\
\text { 'Thomson Navel' }\end{array}$ & + & + & + & \\
\hline 4 & $31 / 04 / 2013$ & Menzel Bouzelfa & A. gossypii & $\begin{array}{l}\text { Citrus sinensis } \\
\text { 'Thomson Navel' }\end{array}$ & + & + & & \\
\hline 5 & $31 / 04 / 2013$ & Menzel Bouzelfa & A. gossypii & Citrus $\times$ limon & + & & & \\
\hline 6 & $31 / 04 / 2013$ & Takilsa & A. gossypii & $\begin{array}{c}\text { Citrus sinensis } \\
\text { 'Washington Navel' }\end{array}$ & + & & & \\
\hline 7 & $31 / 04 / 2013$ & Takilsa & A. gossypii & $\begin{array}{c}\text { Citrus sinensis } \\
\text { 'Washington Navel' }\end{array}$ & + & & & \\
\hline 8 & $31 / 04 / 2013$ & Takilsa & A. gossypii & $\begin{array}{c}\text { Citrus sinensis } \\
\text { 'Washington Navel' }\end{array}$ & + & & & \\
\hline 9 & $31 / 04 / 2013$ & Takilsa & A. gossypii & $\begin{array}{c}\text { Citrus sinensis } \\
\text { 'Washington Navel' }\end{array}$ & & & & \\
\hline 10 & $31 / 04 / 2013$ & Takilsa & A. gossypii & Citrus sinensis & + & & & \\
\hline 11 & $31 / 04 / 2013$ & Takilsa & A. gossypii & Citrus sinensis & + & & & \\
\hline 12 & $31 / 04 / 2013$ & Takilsa & A. gossypii & Citrus sinensis & + & & & \\
\hline 13 & $3 / 05 / 2013$ & Mornag & A. gossypii & Citrus clementina & & + & & \\
\hline 14 & $3 / 05 / 2013$ & Mornag & A. gossypii & Citrus clementina & + & & + & \\
\hline 15 & $3 / 05 / 2013$ & Mornag & A. gossypii & Citrus clementina & + & & & \\
\hline 16 & $3 / 05 / 2013$ & Mornag & A. gossypii & Citrus clementina & & & + & \\
\hline 17 & $3 / 05 / 2013$ & Mornag & A. gossypii & Citrus clementina & & & & \\
\hline 18 & $3 / 05 / 2013$ & Khalidia & A. gossypii & $\begin{array}{l}\text { Citrus sinensis } \\
\text { 'Thomson Navel' }\end{array}$ & + & & & \\
\hline 19 & $3 / 05 / 2013$ & Khalidia & A. gossypii & $\begin{array}{l}\text { Citrus sinensis } \\
\text { 'Thomson Navel' }\end{array}$ & & & + & \\
\hline 20 & $31 / 04 / 2013$ & Grombalia & A. spiraecola & Citrus clementina & + & & & + \\
\hline 21 & $31 / 04 / 2013$ & Grombalia & A. spiraecola & Citrus clementina & + & & & + \\
\hline 22 & 31/04/2013 & Grombalia & A. spiraecola & Citrus clementina & + & & & + \\
\hline 23 & $31 / 04 / 2013$ & Grombalia & A. spiraecola & Citrus clementina & & & & \\
\hline 24 & $31 / 04 / 2013$ & Grombalia & A. spiraecola & Citrus clementina & & + & & + \\
\hline 25 & $31 / 04 / 2013$ & Béni Khalled & A. spiraecola & Citrus $\times$ limon & & & & + \\
\hline
\end{tabular}


Table S1 (continued).

\begin{tabular}{|c|c|c|c|c|c|c|c|c|}
\hline Colony ID & $\begin{array}{l}\text { Sampling } \\
\text { date }\end{array}$ & Collection site & Aphid species & Host plant species & Arsenophonus & $\begin{array}{c}\text { S. } \\
\text { symbiotica }\end{array}$ & $\begin{array}{c}R . \\
\text { insecticola }\end{array}$ & $\begin{array}{c}\mathrm{H} . \\
\text { defensa }\end{array}$ \\
\hline 26 & $31 / 04 / 2013$ & Béni Khalled & A. spiraecola & Citrus sinensis & & & & \\
\hline 27 & $31 / 04 / 2013$ & Béni Khalled & A. spiraecola & Citrus sinensis & & & & \\
\hline 28 & $31 / 04 / 2013$ & Béni Khalled & A. spiraecola & Citrus sinensis & & & & \\
\hline 29 & $31 / 04 / 2013$ & Béni Khalled & A. spiraecola & Citrus sinensis & & & & \\
\hline 30 & $31 / 04 / 2013$ & Menzel Bouzelfa & A. spiraecola & $\begin{array}{l}\text { Citrus sinensis } \\
\text { 'Thomson Navel' }\end{array}$ & & + & + & + \\
\hline 31 & $31 / 04 / 2013$ & Menzel Bouzelfa & A. spiraecola & Citrus $\times$ limon & & & & \\
\hline 32 & $31 / 04 / 2013$ & Menzel Bouzelfa & A. spiraecola & Citrus $\times$ limon & & + & & \\
\hline 33 & $31 / 04 / 2013$ & Selinem & A. spiraecola & Citrus sinensis & + & & & \\
\hline 34 & $31 / 04 / 2013$ & Selinem & A. spiraecola & Citrus sinensis & & & & \\
\hline 35 & $31 / 04 / 2013$ & Takilsa & A. spiraecola & $\begin{array}{c}\text { Citrus sinensis } \\
\text { 'Washington Navel' }\end{array}$ & & & + & \\
\hline 36 & $31 / 04 / 2013$ & Takilsa & A. spiraecola & $\begin{array}{c}\text { Citrus sinensis } \\
\text { 'Washington Navel' }\end{array}$ & & & & \\
\hline 37 & $31 / 04 / 2013$ & Takilsa & A. spiraecola & Citrus sinensis & & & & \\
\hline 38 & $31 / 04 / 2013$ & Takilsa & A. spiraecola & Citrus sinensis & & & & \\
\hline 39 & $2 / 05 / 2013$ & Bou Salem & A. spiraecola & Citrus clementina & & & & \\
\hline 40 & $2 / 05 / 2013$ & Bou Salem & A. spiraecola & Citrus clementina & & & & \\
\hline 41 & $2 / 05 / 2013$ & Bou Salem & A. spiraecola & Citrus clementina & & & + & \\
\hline 42 & $2 / 05 / 2013$ & Bou Salem & A. spiraecola & $\begin{array}{c}\text { Citrus sinensis } \\
\text { 'Washington Navel' }\end{array}$ & & & + & \\
\hline 43 & $2 / 05 / 2013$ & Bou Salem & A. spiraecola & $\begin{array}{l}\text { Citrus sinensis } \\
\text { 'Washington Navel' }\end{array}$ & & & & \\
\hline 44 & $2 / 05 / 2013$ & Jendouba & A. spiraecola & $\begin{array}{l}\text { Citrus sinensis } \\
\text { 'Thomson Navel' }\end{array}$ & & & + & \\
\hline 45 & $2 / 05 / 2013$ & Jendouba & A. spiraecola & $\begin{array}{l}\text { Citrus sinensis } \\
\text { 'Thomson Navel' }\end{array}$ & & & & \\
\hline 46 & $2 / 05 / 2013$ & Jendouba & A. spiraecola & $\begin{array}{l}\text { Citrus sinensis } \\
\text { 'Thomson Navel' }\end{array}$ & & & & \\
\hline 47 & $2 / 05 / 2013$ & Jendouba & A. spiraecola & $\begin{array}{l}\text { Citrus sinensis } \\
\text { 'Thomson Navel' }\end{array}$ & & & & \\
\hline 48 & $2 / 05 / 2013$ & Jendouba & A. spiraecola & $\begin{array}{l}\text { Citrus sinensis } \\
\text { 'Thomson Navel' }\end{array}$ & & & & \\
\hline 49 & $2 / 05 / 2013$ & Jendouba & A. spiraecola & $\begin{array}{l}\text { Citrus sinensis } \\
\text { 'Thomson Navel' }\end{array}$ & & & & \\
\hline 50 & $2 / 05 / 2013$ & Jendouba & A. spiraecola & $\begin{array}{l}\text { Citrus sinensis } \\
\text { 'Thomson Navel' }\end{array}$ & & + & + & \\
\hline 51 & $2 / 05 / 2013$ & Jendouba & A. spiraecola & $\begin{array}{l}\text { Citrus sinensis } \\
\text { 'Thomson Navel' }\end{array}$ & & + & + & \\
\hline 52 & $2 / 05 / 2013$ & Jendouba & A. spiraecola & $\begin{array}{l}\text { Citrus sinensis } \\
\text { 'Thomson Navel' }\end{array}$ & & + & & \\
\hline 53 & $2 / 05 / 2013$ & Jendouba & A. spiraecola & $\begin{array}{l}\text { Citrus sinensis } \\
\text { 'Thomson Navel' }\end{array}$ & & + & & \\
\hline 54 & $3 / 05 / 2013$ & Mornag & A. spiraecola & Citrus clementina & + & + & + & \\
\hline 55 & $3 / 05 / 2013$ & Mornag & A. spiraecola & Citrus clementina & + & & & \\
\hline 56 & $3 / 05 / 2013$ & Mornag & A. spiraecola & Citrus clementina & + & + & + & \\
\hline 57 & 3/05/2013 & Mornag & A. spiraecola & Citrus clementina & & & & \\
\hline 58 & $3 / 05 / 2013$ & Mornag & A. spiraecola & Citrus $\times$ limon & & & & \\
\hline 59 & $3 / 05 / 2013$ & Mornag & A. spiraecola & Citrus $\times$ limon & & & & \\
\hline 60 & $3 / 05 / 2013$ & Mornag & A. spiraecola & Citrus $\times$ limon & & & + & \\
\hline 61 & $3 / 05 / 2013$ & Mornag & A. spiraecola & Citrus $\times$ limon & & & & \\
\hline 62 & $3 / 05 / 2013$ & Khalidia & A. spiraecola & $\begin{array}{l}\text { Citrus sinensis } \\
\text { 'Thomson Navel' }\end{array}$ & + & & & \\
\hline 63 & $3 / 05 / 2013$ & Khalidia & A. spiraecola & $\begin{array}{l}\text { Citrus sinensis } \\
\text { 'Thomson Navel' }\end{array}$ & & & & \\
\hline 64 & $3 / 05 / 2013$ & Khalidia & A. spiraecola & $\begin{array}{l}\text { Citrus sinensis } \\
\text { 'Thomson Navel' }\end{array}$ & & & & \\
\hline 65 & 3/05/2013 & Khalidia & A. spiraecola & Citrus clementina & & & & \\
\hline 66 & 3/05/2013 & Khalidia & A. spiraecola & Citrus clementina & & & & \\
\hline 67 & $3 / 05 / 2013$ & Khalidia & A. spiraecola & $\begin{array}{l}\text { Citrus clementina } \\
\text { Citrus sinensis }\end{array}$ & + & & & \\
\hline 68 & $3 / 05 / 2013$ & Khalidia & A. spiraecola & $\begin{array}{l}\text { 'Maltaise demi- } \\
\text { sanguine' }\end{array}$ & & & & \\
\hline
\end{tabular}

